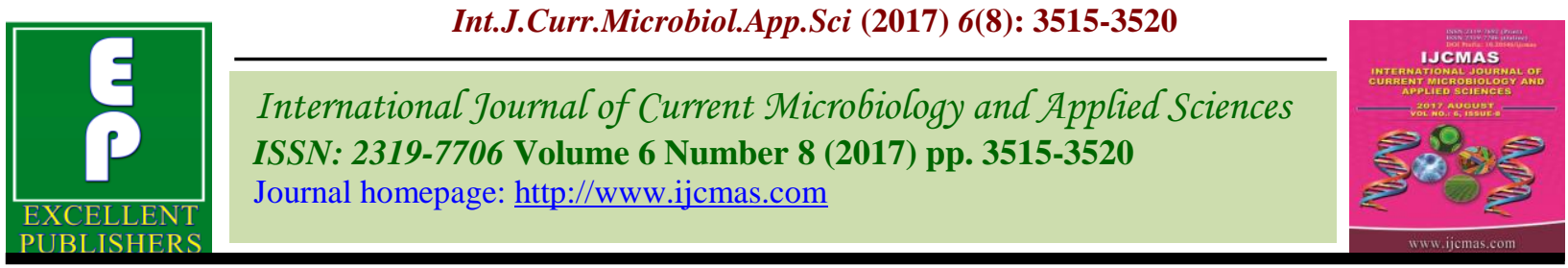

Original Research Article

https://doi.org/10.20546/ijcmas.2017.608.420

\title{
Assessment of Soil Moisture Characteristics Curve for Greenhouse Growing Media
}

\author{
E. Sujitha* and K. Shanmugasundaram \\ Department of Soil and Water Conservation Engineering, Agricultural Engineering College and \\ Research Institute, Kumulur, Trichy, Tamil Nadu, India \\ *Corresponding author
}

\begin{tabular}{|c|c|}
\hline \multicolumn{2}{|r|}{ A B S T R A C T } \\
\hline & \multirow{6}{*}{$\begin{array}{l}\text { Most of the land is kept fallow due to deficiency in soil moisture availability and water } \\
\text { holding capacity of soil. This deficiency is mainly due to insufficient rainfall and lack of } \\
\text { natural water resources. The water holding capacity of a soil is of great value to } \\
\text { agriculture, because it provides a simple means of determining moisture content required } \\
\text { for good plant growth. Area with poor physical properties can be brought under } \\
\text { cultivation, by changing the physical property of the soil. Changing the physical properties } \\
\text { of soil will increase the water holding capacity, but changing the properties for huge area } \\
\text { is practically impossible. This can be made possible by considering small area under } \\
\text { greenhouse which will give higher economic return compared to open field. Study was } \\
\text { undertaken to assess the influence of growing media physical properties on the } \\
\text { characteristics curve and water holding capacity. The growing media properties were } \\
\text { determined for the three treatments }\left(\mathrm{T}_{1} \text {-Soil, } \mathrm{T}_{2} \text {-Soil+Sawdust }(2: 1) \text {, } \mathrm{T}_{3} \text {-Soil+Coirpith }\right. \\
(2: 1) \text { ). The textural class of experimental plot was sandy loam soil. Maximum water } \\
\text { holding capacity among the treatments was observed as } 65 \text { per cent for } \mathrm{T}_{3} \text { followed by } 60 \\
\text { per cent for } \mathrm{T}_{2} \text { and } 33 \text { per cent for } \mathrm{T}_{1} \text {. Quadratic equation was developed for three } \\
\text { treatments to directly predict available soil moisture content from the calibration curve } \\
\text { which will be useful for scheduling irrigation. Out of these three treatments carried } \mathrm{T}_{2} \text { and } \\
\mathrm{T}_{3} \text { was found best with minimal usage of water. }\end{array}$} \\
\hline Keywords & \\
\hline $\begin{array}{l}\text { Physical } \\
\text { properties, Water } \\
\text { holding capacity } \\
\text { and } \\
\text { Characteristics } \\
\text { curve. }\end{array}$ & \\
\hline Article Info & \\
\hline $\begin{array}{l}\text { Accept } \\
27 \text { Jun } \\
\text { Availab } \\
10 \text { Aug }\end{array}$ & \\
\hline & \\
\hline
\end{tabular}

\section{Introduction}

In India, with the growing population, per capita availability of soil and water resources are diminishing day by day and their increasing scarcity for crop production in the country highlights the importance of optimizing its use. In 1960, with 3 billion population over the world, per capita land availability was 0.5 ha but presently, with 6 billion people it is only 0.25 ha and by 2050 , it is projected to reach at 0.16 ha and in future it will be impossible to feed the entire population using open field system of agricultural production only. In the present scenario, to meet the worldwide demand of enhanced production, greenhouse cultivation could serve as a viable solution, facilitating off-season cultivation and protecting crop from unfavorable outdoor conditions with increased profit. Irrigated agriculture depends on the management of two basic natural resources, soil and water. The available water holding capacity and characteristics curve of soil are critical to water management planning for crops. The management decisions of what crops to grow, plant population, when to irrigate, how much to irrigate, how long to 
irrigate, depends on the water holding capacity of soil. By understanding some physical characteristics of the soil, one can better define the strengths and weaknesses of different growing media. Locally available inexpensive material such as sawdust and coirpith were found and selected as a greenhouse growing media mixture with soil to alter the physical properties particularly the water holding capacity.

Main objective of the study is to determine the importance of growing media physical properties, to assess the water holding capacity of the growing media and to determine the soil moisture characteristics curve for soil, soil + sawdust $(2: 1)$, soil + coirpith $(2: 1)$.

\section{Materials and Methods}

\section{Preparation of growing media}

The fine soil is obtained by sieving the soil through a $2 \mathrm{~mm}$ diameter sieve. Three treatments were adopted for this experiment, (i) 3part as soil media (ii) Soil + Sawdust (2:1) (iii) Soil + Coirpith (2:1) sieved soil is used for preparing growing media. This sieved soil was used for finding soil texture by international pipette method, Field capacity and Wilting point by pressure plate apparatus, Soil moisture content by gravimetric method and other physical characteristics such as bulk density, particle density, porosity and water holding capacity by Kneer Rackzowski box, soil moisture tension by using tensiometer.

Physical properties of selected growing media were measured using the following formula.

\footnotetext{
Field capacity $=\frac{\text { weight of moisture held by media at } 0.33 \text { bar }}{\text { weight of dry media at } 0.33 \text { bar }}$

Permanent wilting point $=\underline{\text { weight } \text { of moisture held by media at } 15 \text { ba }}$ weight of dry media at 15 bar
}

Available water $=$ Field capacity moisture Permanent wilting point

Bulk density of the processed soil $\left(\mathrm{g} \mathrm{cm}^{-3}\right)=\frac{\text { Oven dry weight of the media }}{\text { Volume of the air dry media }}$

Particle density of the processed soil $\left(\mathrm{g} \mathrm{cm}^{-3}\right)=\frac{\text { Oven dry weight of the media }}{\text { Particle volume of the media }}$

Total porosity $=1-\left(\frac{\text { Bulk density }}{\text { Paticle density }}\right) \times 100$

Water holding capacity $=\left(\frac{\text { Total water in the wet media }}{\text { oven dry weight of total media }}\right) \times 100$

Moisture content $=\frac{\text { Weight of moist soil }- \text { Weight of dry media }}{\text { weight of dry media }}$

Determination of the soil moisture characteristics curve by using tensiometer

Tensiometers provide a direct measure of the tenacity with which water is held by soils. It is used to measure the soil moisture content. The tensiometer consists of porous ceramic cup filled with water which is buried in the soil at any desired depth and connected to a water filled tube with vacuum gauge. The scales are generally calibrated in either one hundredth of an atmosphere or in centimeter of water. When the tensiometer is placed in the soil where the tension measurement is to be made, the bulk water inside the porous cup oozes out and tends to equilibrate with soil water through the pores in the ceramic cup. Soil water, being generally at subatmospheric pressure, exercises a suction which sucks a certain amount of water from the rigid and airtight tensiometer, thus causing a drop in its hydrostatic pressure. This pressure is indicated by the vacuum gauge. Any increase in tension that occurs as the soil dries causes the gauge reading to increase, which can be read above ground. Conversely, an increase in soil-water content reduces tension and lowers the reading.

To determine moisture characteristics curve, tensiometers placed at rootzone depths to 
measures the soil moisture tension. Irrigation was applied till tension reaches ' 0 ' atmosphere in vacuum gauge. Daily the moisture content of the three treatment media was measured by using gravimetric method. Tension was recorded for respective soil moisture content. This process was continued until it reached the permanent wilting point. Calibration curve was drawn with observed tensiometer reading on $\mathrm{X}$ axis and media moisture content on $\mathrm{Y}$ axis.

\section{Results and Discussion}

\section{Soil texture}

Soil texture is a reflection of the particle size distribution of a soil. The textural analysis of existing soil as per the triangular diagram showed sandy loam soil (sand $72.8 \%$, silt $16.1 \%$, clay $10.2 \%$ ).

\section{Physical properties}

Physical properties (Bulk density, particle density, porosity, maximum water holding capacity, field capacity, wilting point and available water) of 3 treatments $\left(\mathrm{T}_{1}\right.$ - soil media, $\mathrm{T}_{2}$ - soil+ sawdust (2:1), $\mathrm{T}_{3^{-}}$soil+ coirpith (2:1)) were determined and tabulated in table 1 .

The growing media moisture characteristics curve is of great value in precession farming, because it provides a simple means to determine adequate moisture contents required for media for good plant growth.
Hence a study was undertaken to determine the influence of growing media physical properties on characteristics curves and water holding capacity. Table 1 show that the bulk density, particle density, porosity, field capacity and wilting point were found to be highest in $T_{1}$ followed by $T_{2}$ and $T_{3}$. Available water was held in soil pores by forces that depend on the size of the pore and the surface tension of water. The closely bound particles have the smaller pores and it has stronger attraction between soil and water thus results in higher water holding capacity of the soil. However compared with treatments $\mathrm{T}_{2}$ and $\mathrm{T}_{3}$, $\mathrm{T}_{3}$ has been observed that available water was higher because of higher retention capacity of coirpith, though it has low bulk density.

Saturation brings all the pores including airfilled porosity with full of water it is known as Maximum water holding capacity of the media. The maximum water holding capacity among the treatments were observed as 65 per cent for $\mathrm{T}_{3}$ (Soil + Coirpith (2:1)) followed by 60 per cent for $\mathrm{T}_{2}$ (Soil + Sawdust (2:1)) and 33 per cent $T_{1}$ soil. The water release characteristics of the soil are indicators of the moisture available for crops. When coirpith mixed with soil media in the ratio of $2: 1$ shows the $32 \%$ and sawdust mixed with soil media in the ratio of $(2: 1)$ shows $5 \%$ higher moisture holding capacity than the soil media.

Hence result shows that the treatment $\mathrm{T}_{2}$ and $\mathrm{T}_{3}$ perform well as a growing media in greenhouse with $5 \%$ difference in maximum water holding capacity.

Table.1 Physical properties of the growing media

\begin{tabular}{|c|c|c|c|c|c|c|c|c|}
\hline S. No. & Media & $\begin{array}{c}\text { Bulk } \\
\text { density } \\
\left(\mathbf{g ~ c m}^{-3}\right)\end{array}$ & $\begin{array}{c}\text { Particle } \\
\text { density } \\
\mathbf{c m}^{-\mathbf{3}} \mathbf{( g}\end{array}$ & $\begin{array}{c}\text { Porosity } \\
\mathbf{( \% )}\end{array}$ & $\begin{array}{c}\text { Maximum } \\
\text { water } \\
\text { holding } \\
\text { capacity } \mathbf{( \% )}\end{array}$ & $\begin{array}{c}\text { Field } \\
\text { capacity } \\
\mathbf{( F C ) ~ @ ~} \\
\mathbf{1 / 3} \text { bar }\end{array}$ & $\begin{array}{c}\text { Wilting } \\
\text { point \% } \\
\text { (WP) @ } \\
\mathbf{1 5} \text { bar }\end{array}$ & $\begin{array}{c}\text { Available } \\
\text { water \% } \\
\text { (FC-WP) }\end{array}$ \\
\hline 1 & $\mathrm{~T}_{1}$ & 1.42 & 2.6 & 53 & 33 & 23.6 & 10 & 13.6 \\
\hline 2 & $\mathrm{~T}_{2}$ & 0.9 & 1.5 & 43 & 60 & 25 & 12.4 & 12.6 \\
\hline 3 & $\mathrm{~T}_{3}$ & 0.8 & 1.4 & 42 & 65 & 28.5 & 13 & 15.5 \\
\hline
\end{tabular}


Table.2 Quadratic equation on characteristics curve for three treatments

\begin{tabular}{|c|c|c|c|c|}
\hline S. No. & Treatments & Soil media & Quadratic equation & $\mathbf{R}^{2}$ \\
\hline $\mathbf{1}$ & $\mathrm{T}_{1}$ & Soil & $\mathrm{y}=0.003 \mathrm{x}^{2}-0.575 \mathrm{x}+28.86$ & 0.992 \\
\hline $\mathbf{2}$ & $\mathrm{T}_{2}$ & Soil + Sawdust $(2: 1)$ & $\mathrm{y}=0.007 \mathrm{x}^{2}-0.888 \mathrm{x}+38.41$ & 0.979 \\
\hline $\mathbf{3}$ & $\mathrm{T}_{3}$ & Soil + Coirpith $(2: 1)$ & $\mathrm{y}=0.004 \mathrm{x}^{2}-0.659 \mathrm{x}+38.19$ & 0.942 \\
\hline
\end{tabular}

Fig.1 Soil moisture charateristics curve (SMC) for Soil

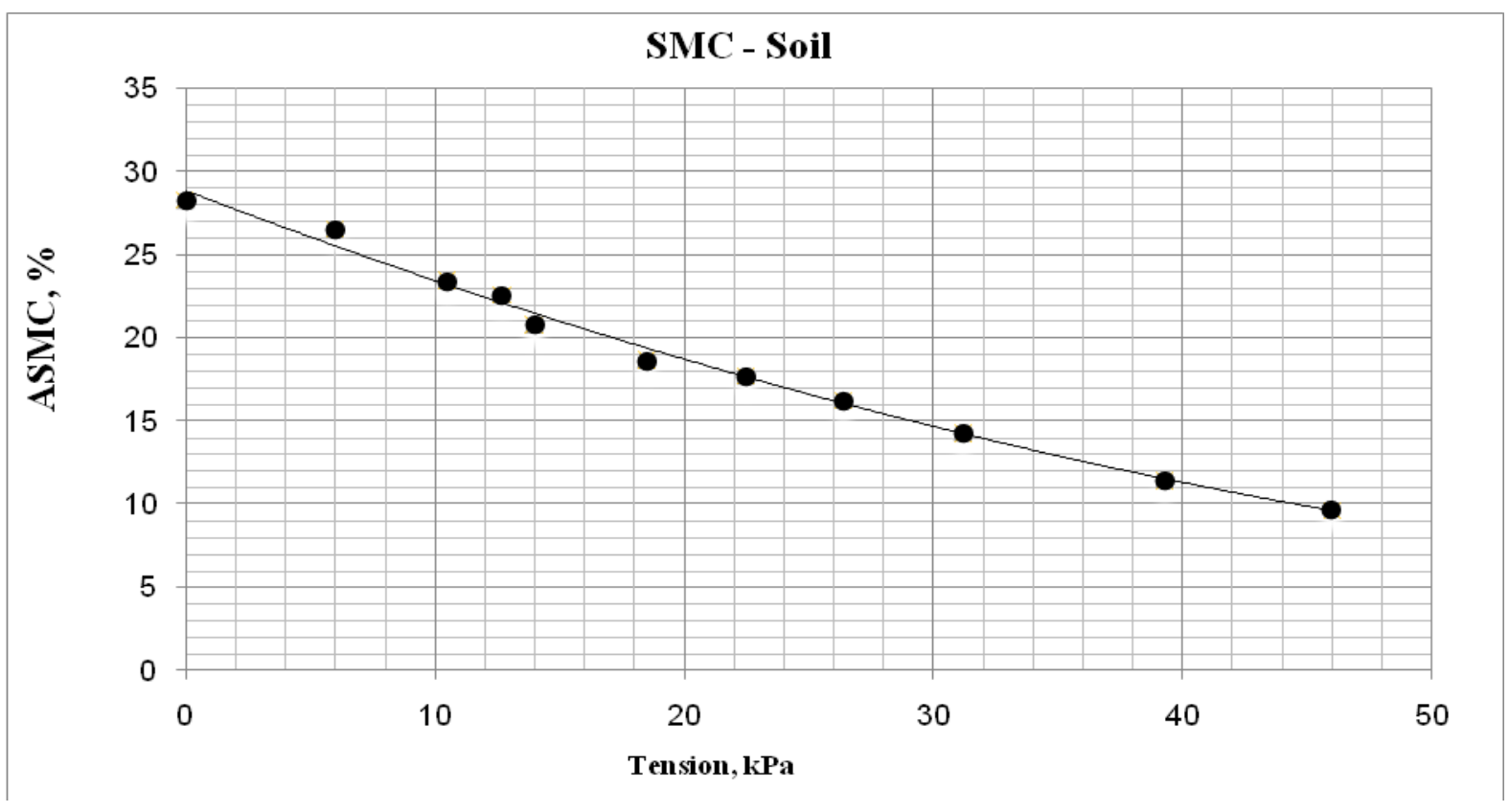

Fig.2 Soil moisture charateristics curve for Soil + Sawdust (2:1)

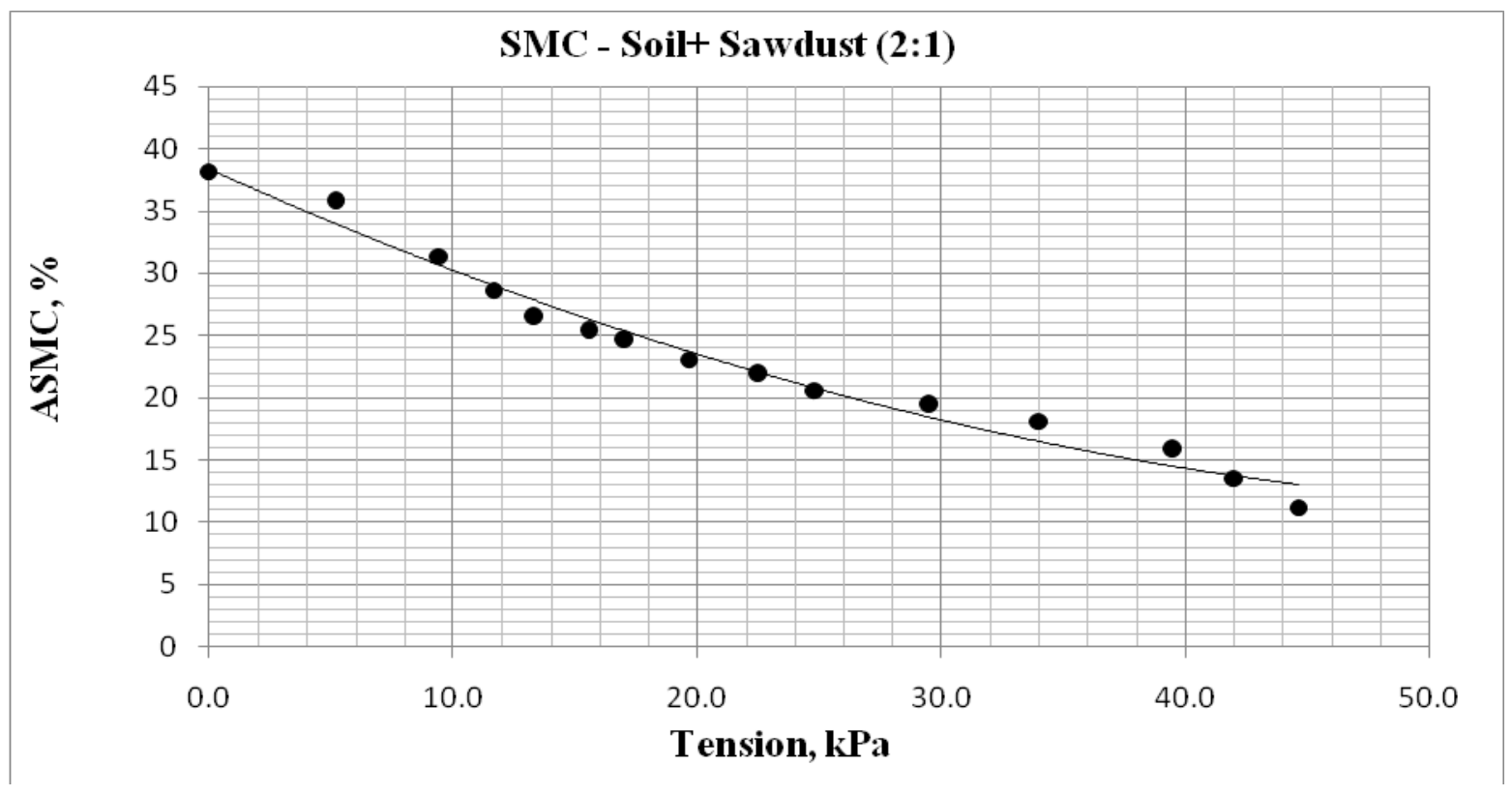


Fig.3 Soil moisture charateristics curve for Soil + Coirpith (2:1)

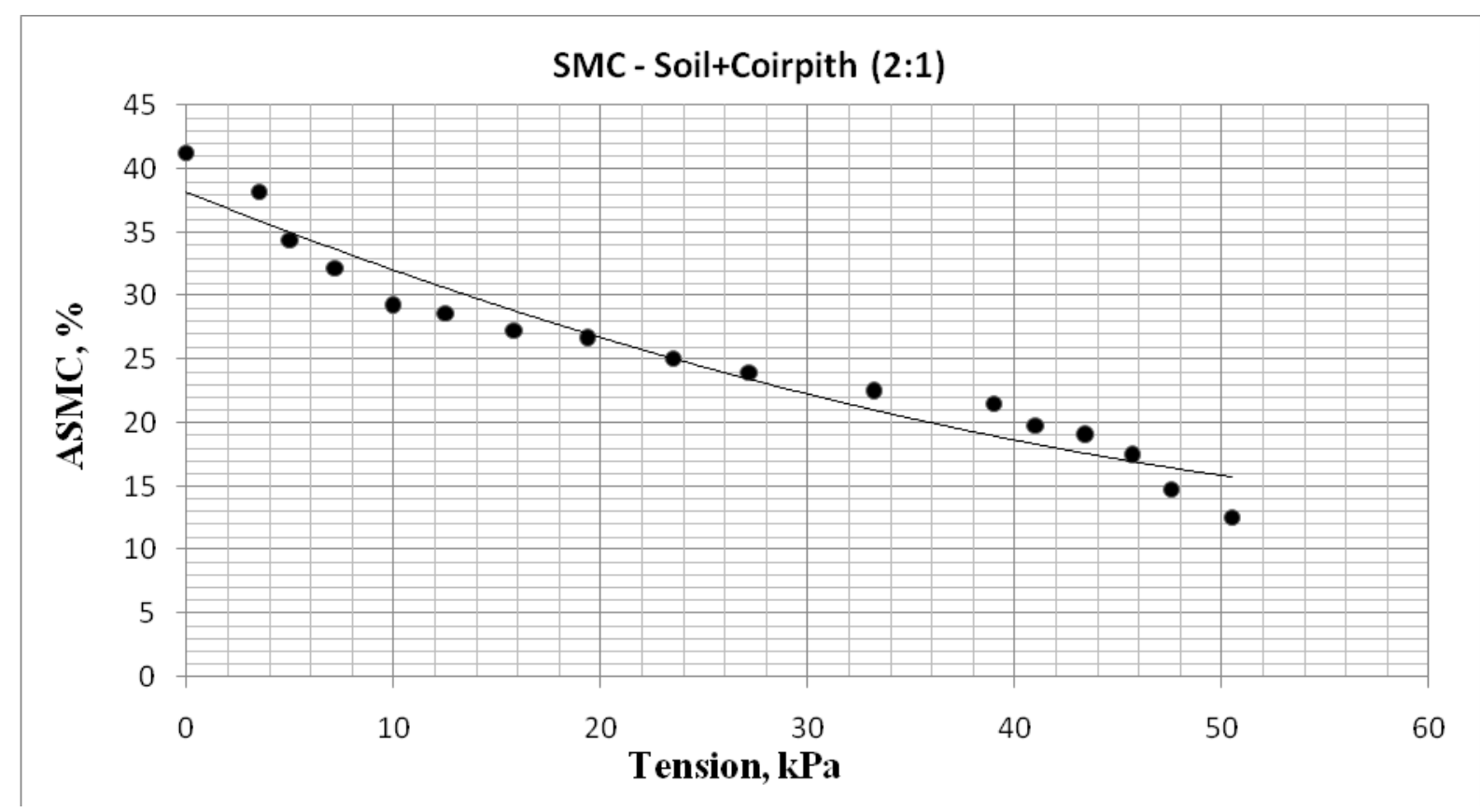

\section{Soil moisture characterstics curve}

Soil moisture characterstics curve between available soil moisture content Vs tension were drawn for three treatments.

Calibration curve was drawn with observed tensiometer reading on $\mathrm{X}$ axis and soil moisture content on $\mathrm{Y}$ axis (Figs. 1, 2, 3). Based on this calibration curve irrigate the field when the tensiometer indicates that the metric suction has reached known prescribed values of the respective crops.

To identify proper soil water potential the calibration curve is used. Quadratic equation was developed for $T_{1}, T_{2}$ and $T_{3}$ treatments with coefficient of determination is 0.992 , 0.979 and 0.942 respectively was shown in table 2. Hence to know the soil moisture content in field, the known tension value can directly used in the developed respective quadratic equation which will gives the soil moisture content. It is useful to schedule irrigation without the calibration chart each time of irrigation.
Lack of aeration, drainage and water holding capacity makes soil unsuitable for the production of plants in containers. To improve this situation soilless growing media have been developed.

These media are all inert, sterile soil substrates that have excellent aeration drainage and water holding capacity properties. Locally available and inexpensive media such as coirpith and sawdust were found to be used as substrate in proper proportion with soil to improve the water holding capacity of the growing media that provides new opportunities for ground based or potting mixture in greenhouse.

This is responsible for allowing good aeration around the roots of plants and retaining water for longer duration.

The behaviour of the tested variables indicated, the mixture of coconut fibre and sawdust with soil are two suitable media to be used in greenhouse cultivation instead of using soil alone as a growing media. 


\section{References}

Boso, M., Romero, E., Tarantino, A., 2003. The use of different suction measurement techniques to determine water retention curves. In: Schanz T (ed.) Unsaturated soils: Experimental studies. Springer-Verlag Berlin, 171181.

Das, T.H., Sarkar, D., Bera, R., and Gajbhiye K.S., 2005.Water retention characteristics of some typical inceptisols developed on all plain of Damodar catchment's (part), West Bengal, Ind. Soil. Cons., 33(2): 123127.

Malay, C., and Sreedeep, S., 2011. An investigation on influence of soil activities on tensiometric measurement in soil, J.Environ. Res. Develop., 5(2): 300-307.

Seenarious Lawes, R.A., 2009. Integrating effects of climate and plant available soil water holding capacity. European conference on precession agriculture, Montpellier, France. 113(3): 297-305.

Singh, R., and Kundu, D.K., 2005. Prediction of profile water storage capacity for major soil groups of Orissa, Ind. J.Soil Cons., 33(2): 128-13.

Sujatha, K.N., Kavya, G., Manasa, P., and Divya, K. 2016. Assessment of Soil Properties to Improve Water Holding Capacity in Soils, International Research Journal of Engineering and Technology, 3(3).

Vengadaramana, A., and Jashothan, J. 2012. Effect of organic fertilizers on the water holding capacity of the soils in different terrians, J. Nat. Prod. Plant Resource, 2 (4):500-503.

Viji, R., Prasanna, P., and Rajesh, 2012. Assessment of water holding capacity of major soil series of Lalgudi, Trichy, India. Journal of Environmental Research and Development, 7(1A).

\section{How to cite this article:}

Sujitha, E. and Shanmugasundaram, K. 2017. Assessment of Soil Moisture Characteristics Curve for Greenhouse Growing Media. Int.J.Curr.Microbiol.App.Sci. 6(8): 3515-3520. doi: https://doi.org/10.20546/ijcmas.2017.608.420 